\title{
Linkage Mechanisms among key Actors in Rice Innovation System in Southeast Nigeria
}

\author{
Emodi, A. I and Madukwe, M. \\ Department of Agricultural Extension \\ University of Nigeria, Nsukka.
}

\begin{abstract}
A nation's ability to solve problems and sustain economic growth depends partly on its capabilities in science, technology, and innovation. In assessment of linkage mechanisms among key actors in rice innovation system in southeast Nigeria, actors were classified into six major groups according to their main activity in the system namely research agency, policy personnel, technology transfer agencies, farmers, marketers and consumers. These constituted the population of the study. A total sample size of 539 respondents, made up of 40 researchers, 76 policy personnel, 96 technology transfer agencies, 196 farmers, 51 marketers and 80 consumers were used. Percentages and means were used in data analysis. The study revealed that among the actors in rice innovation system, NCRI and IITA had link with technology transfer agencies, IITA had link with the Ministry of Agriculture. the Ministry of Agriculture had link with farmers $(\bar{X}=2.51)$ and NAFDAC had link with researchers ( $\bar{X}=2.83$ ). Among technology transfer agencies, $A D P$ had link with researchers $(\bar{X}=3.00)$, policy personnel ( $\bar{X}=2.88)$, farmers $(\bar{X}=3.00$ ) and Federal Ministry of Commerce had link with researchers ( $\bar{X}=2.73$ ). Marketers had link with policy personnel $(\bar{X}=2.72)$ and farmers ( $\bar{X}=2.68)$, while consumers had link with farmers $(\bar{X}=2.72)$. The major linkage mechanisms that existed among the actors was dissemination of knowledge and information $(\bar{X}=3.00)$. The study concludes that for increase in rice production in southeast Nigeria, there is need for strong linkages among the actors in the rice innovation system.
\end{abstract}

\section{INTRODUCTION}

Nigeria is in the grip of food crisis since rice became staple food; as rise in domestic demand/consumption of rice in Nigeria far exceeds local production, precipitating an increase in rice importation bill to as high as $\$ 695$ million US dollars in 2007 (Emodi and Madukwe, 2008; Alufohai and Ojogho, 2009). Consequently, emphases by government and other stakeholders have been to improve domestic production of rice to meet the increasing demand; and achieve the Millennium Development Goals (MDGs). However, the goal of increased productivity can be best achieved by coupling the most appropriate available 
technologies. This implies that resources allocated to rice production must be efficiently utilized. Technologies exist to address these problems, but their adoption is constrained by lack of information packaged in appropriate formats, and poor communication channels (Tran, 1997).

A nation's ability to solve problems and sustain economic growth depends partly on its capabilities in science and technology, and innovation (Juma and Yeecheong, 2005). Thus for innovation to be effective in rice production, the linkages between the different stakeholders must be formed and strengthened. Thus effective participation of different actors portrays organizational mandates, objectives, motivation, extension approaches and sources of funding. This means that innovation with good linkage will aid increase in rice production. What level of linkages exits between the key actors? Which linkage mechanism are used by these actors?

\section{Purpose of the Study}

1. examine the level of linkages among key actors in rice innovation system;

2. ascertain the linkage mechanism used by the actors;

\section{METHODOLOGY}

The study population constituted all stakeholders in rice innovation system in four states (Abia, Anambra, Ebonyi and Enugu) of southeast agro-ecological zone of Nigeria. These actors (market/demand, enterprise, research and training, diffusion and infrastructure) were classified according to their related activities as follow: research, policy personnel, technology transfer agencies, farmers, marketers and consumers.

Forty researchers were purposively selected from the six agencies as follow: National Cereals Research Institute (NCRI) (9), International Institute for Tropical Agriculture (IITA)(7), West Africa Rice Development Association (WARDA) (6), Plant Quarantine Service (PQS) (7), International Network for the Generic Evaluation of Rice (INGER- AFRICA) (6)

From seven policy agencies, three agencies were purposively selected as follow: Federal Ministry of Agriculture (FMA) (36) nine from each of the four states, the National Agency for Food and Drug Administrations and Control (NAFDAC), 20 , five from each state, the Nigerian Agricultural Cooperative and Rural Development Bank (NACRDB) 20, five from each state.

Similarly, out of four technology transfer agencies, one agency (ADP) was purposively selected. In each sate ADP (Abia, Anambra, Ebonyi and Enugu) five directors of extension, human resources development and planning, monitoring and evaluation (DES), one project manager (PM), three zonal extension officers (ZEO), five subject matter specialist (SMS) and ten block extension supervisors were selected. One hundred and ninety six farmers were selected. Twelve markets each were selected from the biggest markets in each of the states capitals. 
Twenty consumers (heads of households) were selected from each of the states capitals. Four hundred and ninety six (496) questionnaires were properly completed and used in the analysis.

In measuring the level of linkage, respondent were asked to rate on a four point Likert-type scale the level of linkage they have with other actors in the innovation system. The primary data were obtained through questionnaires and interview schedules for literate and illiterate respondents. Descriptive statistics, consisting of frequencies, percentage and mean scores were used for analysis.

\section{RESULTS AND DISCUSSION}

\section{Linkages among the actors in rice innovation system}

\section{Researchers level of linkage with other actors}

Table 1 reveals that NCRI had link with technology transfer agencies while IITA had link with technology transfer agencies and policy personnel in rice innovation system. This implies that researchers link with actors may promote their mandates in line with their set objectives. On the other hand researchers not having links with the actors may likely threaten the objectives, mandates and financial position of the agency. This highlights the complex relationships and interactions between actors and the organizational and institutional learning behaviors and practices that characterize the system of innovation (Spielman, 2006).

Generally IITA had a fairly good link ( $\bar{X}=2.51)$, while NCRI had a weak loose link $(\bar{X}=1.88)$, with other actors in rice innovation system. The finding suggests that the researchers might be working in isolation, which might generate a lot of discrepancies in production and dissemination of knowledge in rice innovation system. 
TABLE 1: Mean distribution of researchers link with other actors in rice innovation system

\begin{tabular}{lccccccc}
\hline Organisations & Researchers & $\begin{array}{c}\text { Policy } \\
\text { personnel }\end{array}$ & $\begin{array}{c}\text { Technology } \\
\text { transfer } \\
\text { Agencies }\end{array}$ & Farmers & Marketers & Consumers & $\begin{array}{c}\text { Overall } \\
\text { mean }\end{array}$ \\
\hline NCRI & - & 2.18 & 2.61 & 0.00 & 2.26 & 2.35 & 1.88 \\
IITA & - & 2.60 & 3.00 & 2.42 & 2.18 & 2.35 & 2.51 \\
F M A & 2.18 & - & 0.41 & 2.51 & 2.08 & 2.21 & 1.88 \\
NAFDAC & 2.83 & - & 1.03 & 1.99 & 2.43 & 1.68 & 1.99 \\
ADP & 3.00 & 2.88 & - & 3.00 & 2.18 & 2.35 & 2.68 \\
Farmers & 1.48 & 1.31 & - & 2.25 & 2.30 & 1.89 & 1.85 \\
Cooperatives & 3.00 & 2.82 & 3.00 & - & 2.43 & 2.84 & 2.82 \\
Farmers & 0.00 & 2.79 & 1.56 & 2.68 & - & 2.36 & 1.88 \\
Marketers & 1.54 & 1.56 & 2.72 & 2.30 & - & 1.53 \\
Consumers & 0.00 & 1.00 & & & & & \\
\hline
\end{tabular}

\section{Policy personnel level of linkage with other actors}

The mean scores show that the FMA had fairly good link with farmers $(\bar{X}=2.51)$ and a weak link with researchers $(\bar{X}=2.18)$, technology transfer agencies $\bar{X}=0.41)$, marketers $(\bar{X}=2.08)$ and consumers $(\bar{X}=2.21)$ in rice innovation system. Similarly NAFDAC had a fairly good link with researchers $(\bar{X}=2.83)$, while there was a weak link between NAFDAC and technology transfer agencies ( $\bar{X}=1.03)$, farmers $(\bar{X}=1.99)$, marketers $(\bar{X}=2.43)$ and consumers $(\bar{X}=1.68)$ in rice innovation system. Lack of linkage affects the quality of knowledge generation and knowledge management upon which the long term success of rice innovation system depends.

The overall mean scores of policy personnel show that NAFDAC $(\bar{X}=1.99)$ and FMA ( $\bar{X}=1.88)$ had very weak link with other actors in rice innovation system. The weak linkages between the policy personnel and other actors may be an indication of the disconnection between agricultural policy and stakeholder practice in Nigeria. It portrays a situation in which stakeholders are not taken into confidence in policy formation. This runs contrary the requirement of the innovation system perspective and a disincentive to the development of the rice industry. 


\section{Technology transfer agencies level of linkage with other actors}

The mean scores reveal that ADP had a good linkage with researchers $(\bar{X}=3.00)$,, policy personnel $(\bar{X}=2.88)$, and farmers $(\bar{X}=3.00)$ in rice innovation system respectively, and a weak linkage with marketers $(\bar{X}=2.18)$, and consumers $(\bar{X}=2.35)$. The linkage between ADP as a technology transfer agency was expected because ADP by the nature of her mandate is part of the ministry of agriculture, work closely with researchers to source agricultural technology for farmers. The relatively good linkage existing between ADP and other actors is to some extent a measure of the effectiveness of ADP in the rice innovation system in the southeast. This process provides a base for the actors to share related technology knowledge and information in rice innovation system. Technology transfer involves complex processes consisting of diverse structures and relationship of actors aimed at enhancing innovations (Madukwe, Okoli and Eze, 2002).

Farmers Cooperatives had a very weak link $(\bar{X}=1.85)$ with other actors in rice innovation system. This is an indication of the low level of cooperative activities particularly among farmers in the rice industry. This situation will reduce the capability of the farmers to bargain for credits, input, infrastructure and penetrate new markets.

\section{Farmers level of linkage with other actors}

Data in Table 1 show that the farmers had a fairly good linkage with researchers $(\bar{X}=3.00)$, policy personnel $(\bar{X}=2.82)$, technology transfer agencies $(\bar{X}=3.00)$ and consumers $(\bar{X}=2.84)$ in rice innovation system, however, they had a weak linkage with marketers $(\bar{X}=2.43)$. The farmers' linkage with researchers, policy personnel, technology transfer agencies and consumers depend not only on how actors perform individually but also on how they interact with each other as elements of a collective system of knowledge that is creative and useful. Lack of farmers' linkage with marketers is not surprising, since rice market does not convey a reward to quality from the consumers to the farmers and further upstream to the researchers (Lancon et al, 2003).

Generally, farmers had good link ( $\bar{X}=2.82$ ) with other actors (researchers, policy personnel, technology transfer agencies, marketers, consumers) in rice innovation system. This is not surprising since farmers are at the centre of knowledge in rice innovation system. Through farmers' strong link, other actors become sensitive to the demands of the rice innovation system.

\section{Marketers level of linkage with other actors}

Entries in Table 1 show that marketers had a fairly good link with policy personnel $(\bar{X}=2.72)$ and farmers $(\bar{X}=2.68)$ in rice innovation system. The marketers had a very weak link with researchers $(\bar{X}=0.00)$, technology transfer agencies $(\bar{X}=1.56)$ and consumers $(\bar{X}=2.36)$ in rice innovation system. This good linkages between the marketers and policy personnel and farmers promotes has the potential of promoting information flow and knowledge within the rice innovation system. The 
weak linkages between the marketers and technology transfer agencies, research and consumers reveal a general level of weakness within the rice innovation system. The situation is capable of limiting the flow of information and poor performance of the rice innovation system considering that market is a pull factor in innovation systems.

\section{Consumers level of linkage with other actors}

The consumers had fairly good linkage with farmers $(\bar{X}=2.72)$ and a weak linkage with researchers $(\bar{X}=0.00)$, policy personnel $(\bar{X}=1.54)$, technology transfer agencies $(\bar{X}=1.56)$ and marketers $(\bar{X}=2.31)$. The fairly good linkage between consumers and farmers was not unexpected, because the overall effort of the farmer is to meet consumers needs. According to Webb, (1979), if the taste, texture, aroma, or appearance demanded by consumers are not provided by farmers, the rice innovation system will be greatly impaired. This implies that the more the consumers rice preference is satisfied, the stronger their link with farmers in rice innovation system. Generally, consumers, show weak link $(\bar{X}=1.53$ ) with other actors (researchers, policy personnel, technology transfer agencies, farmers, marketers) in rice innovation system.

\section{Linkage mechanisms used by actors in rice innovation system}

Linkage mechanisms are tools employed by two or more organization to share resources in an attempt to achieve a common objective. Entries in Table 2 show that the actors used the following linkage mechanism; dissemination of knowledge and information ( $\bar{X}=3.00)$, Joint problem identification ( $\bar{X}=2.72$ ), joint seminar and workshop training $(\bar{X}=2.65)$, joint demonstration trials $(\bar{X}=2.54)$, evaluation of reports $(\bar{X}=2.53)$, evaluation of field visits $(\bar{X}=2.51)$, joint research activities $(\bar{X}=2.49)$. Dissemination of knowledge and information was ranked as the most important linkage mechanism used by actors in the rice innovation system. This is expected as most of the actors carry out dissemination and in some cases information emanating from other actors. The result revealed that the actors used varieties of linkage mechanisms. Actors in the research institutions used to a great extent the following mechanisms: dissemination of knowledge and information $(\bar{X}=3.00)$, joint problem identification $(\bar{X}=3.00)$, joint seminar and workshop

training $(\bar{X}=3.00)$, joint demonstration trials $(\bar{X}=3.00)$, evaluation of field visits $(\bar{X}=3.00)$, joint research activities $(\bar{X}=3.00)$, and evaluation of reports $(\bar{X}=2.83)$, Actors in the research intuitions were followed closely by actors in the technology transfer agencies, actors in policy institutions and farmers in that order, in terms of extent of use of the linkage mechanism. This finding points to the important role expected of the researchers in kick starting and enhancing the innovation system. 
TABLE 2: Mean distribution of linkage mechanisms used by actors in rice innovation system*

\begin{tabular}{|c|c|c|c|c|c|c|}
\hline \multirow[t]{4}{*}{ Linkage mechanisms } & Researchers & $\begin{array}{l}\text { Policy } \\
\text { personnel }\end{array}$ & $\begin{array}{l}\text { Technology } \\
\text { transfer }\end{array}$ & Farmers & Grand & \multirow[t]{4}{*}{ Rank } \\
\hline & \multicolumn{5}{|c|}{ Agencies } & \\
\hline & Mean & Mean & Mean & Mean & Mean & \\
\hline & $(\bar{X})$ & $(\bar{X})$ & $(\bar{X})$ & $(\bar{X})$ & $(\bar{X})$ & \\
\hline $\begin{array}{l}\text { Dissemination of } \\
\text { knowledge and } \\
\text { information }\end{array}$ & 3.00 & 3.00 & 3.00 & 3.00 & 3.00 & $1^{\mathrm{st}}$ \\
\hline $\begin{array}{l}\text { Joint problem } \\
\text { identification }\end{array}$ & 3.00 & 2.08 & 3.00 & 2.80 & 2.72 & $2^{\text {nd }}$ \\
\hline $\begin{array}{l}\text { Joint seminar and } \\
\text { workshop training }\end{array}$ & 3.00 & 2.61 & 2.43 & 2.58 & 2.65 & $3^{\text {rd }}$ \\
\hline $\begin{array}{l}\text { Joint demonstration } \\
\text { trials }\end{array}$ & 3.00 & 2.12 & 2.85 & 2.19 & 2.54 & $4^{\text {th }}$ \\
\hline Evaluation of reports & 2.83 & 2.74 & 2.67 & 1.90 & 2.53 & $5^{\text {th }}$ \\
\hline Evaluation of field visits & 3.00 & 2.82 & 2.21 & 2.04 & 2.51 & $6^{\text {th }}$ \\
\hline Joint research activities & 3.00 & 2.25 & 2.65 & 2.09 & 2.49 & $7^{\text {th }}$ \\
\hline
\end{tabular}

${ }^{*}$ Max. mean $=3$

\section{CONCLUSION}

The results generally showed that farmers had strong link with researchers, policy personnel, technology transfer agencies, marketers and consumers. Researcher (IITA) had a fair good link with the other actors. Actors in policy, technology transfer agencies, marketers and consumers had weak link with other actors in the rice innovation system. The study concludes that for increase in rice production, there is need for strong linkage mechanisms among the actors in rice innovation system.

To achieve increase in rice production, the actors should be encouraged through policy to use more varieties of linkage mechanisms to enhance networking and knowledge sharing and learning. Policies and programs to strengthen innovative capabilities among stakeholders in rice innovation system should be pursued. Similarly, effort should be directed at creating more space for both public and private sector service providers and other actors to participate and cooperate within smallholder innovation networks. It is important that periodic evaluation of the rice innovation system be undertaken so as to know at what point to make amends and adjustments. 


\section{REFERENCES}

Afolabi, J A. (2009). An assessment of garri marketing in south-west Nigeria. Journal of social science, vol 21(10, pp. 33-34. http://www.krepublishers.com/on-journals/jas/1. (retrieved, 5th june 2009)

Emodi, A.I and Madukwe, M.C. (2008). A review of policies, acts and initiatives in rice innovation system in Nigeria. Journal of Agricultural Extension, 12 (2), pp. $76-83$

Madukwe, M.C., Okoli, E.C. and Eze, S.O. (2002).Analysis and comparison of the agricultural development programme and University agricultural technology transfer systems in Nigeria. ATPS Working Paper Series No. 35

http://www.atpsnet.org/pubs/workingpaper/ working\%20paper\%20series\%2035.pdf (retrieved, 1st February 2010)

Henggen Fan (2010). Halving hunger: meeting the First Millennium Development Goal (MDG) through business as unusual. International Food Policy Research Institute (IFPRI) Washington D. C.

Juma, C and Yee-Cheong, L. (2005). Innovation: Applying knowledge to development (UN millennium project, task Force on science, technology and innovation). Earthscan, London. pp.38. http://www.unmillenniumproject.org/reports/index.htm (retrieved, 7th July 2000)

Spielman, D. (2006). Developing the art and science of innovation systems inquiry: Alternative tools and methods and applications to Sub-Saharan African agriculture. Paper prepared for the innovation Africa symposium Kampala Uganda, 21-23 November.

Tran, D.V. (1997). World rice production: main issues and technical possibilities .In: Proceedings of second technical consultation of FAO/REU/RNE Interregional Co-operative Research Network on Rice Under Mediterranean Climate, 4-5 Sept.,Arles, France, Centre International de hautes etudes agronomiques Mëditerranëennes (CIHEAM), vol. 24:2.

Webb, B.D. (1979). Rice quality and grades. In: Rice production and utilization. AVI Publishing Company, Inc. Wesport, Connecticut. pp. 15 